\title{
REFLECTIONS
}

McGill Journal of Medicine

\section{A Medical Student's Perspective on "Fighting for a Hand to Hold"}

\author{
Susan Joanne Wang ${ }^{1}$
}

${ }^{1}$ McGill University, Montreal, QC, Canada

\section{Correspondence}

Susan Joanne Wang

Email: susan.wang2@mail.mcgill.ca

Publication Date

June 12, 2021

MJM 2021 (19) 21

https://doi.org/10.26443/mjm.v19i1.830

\section{McGill}

\section{Journal of Medicine}

www.mjmmed.com

\section{(c) (i) (2) (2)}

This work is licensed under a Creative Commons BY-NC-SA 4.0 International License.

\section{ABSTRACT}

Fighting for a Hand to Hold by Dr. Samir Shaheen-Hussain is a heartbreaking and compelling read depicting the history of injustices, terror and trauma inflicted upon Indigenous children by the Canadian medical system. As an emergency pediatrician at the McGill University Health Centre and associate professor at McGill University, Dr. ShaheenHussain weaves his clinical experiences and long-standing advocacy efforts alongside archival research to shed insight on medical colonialism. This piece is structured in two parts: a book review followed by a personal reflection. It is accompanied by a podcast interview with Dr. ShaheenHussain in which he discusses his social justice work, his book, and advocacy advice for students in healthcare. This book review highlights the importance of Fighting for a Hand to Hold as a seminal piece of literature for all healthcare professionals and trainees across Canada. In the personal reflection, the author considers their own experiences with race and racism as a person of colour, settler Canadian, and medical student. This reflection concludes by advocating for more emphasis on Indigenous health in Canadian medical education and practice.

\section{KEYWORDS}

Indigenous health, Book review, Medical colonialism, Race, Medical education

\section{1 | FIGHTING FOR A HAND TO HOLD: A BOOK REVIEW}

Written by physician-author Dr. Shaheen-Hussain, (1) Fighting for a Hand to Hold: Confronting Medical Colonial- ism Against Indigenous Children in Canada is a four-part book that brings together first-hand accounts from victims and witnesses, archival material and scholarly documents including peer-reviewed research and memoirs. While the book establishes a rich historical context, the 
author simultaneously ensures that readers never falter in understanding the modern-day relevance of these issues. Alongside perspectives from Indigenous scholars, the author accomplishes this by highlighting the recent \#aHandtoHold campaign. Fighting for a Hand to Hold serves to anchor the past to the present through the author's description of his own grassroots efforts that ended the decades-long practice in Quebec of prohibiting caregiver accompaniment of Indigenous children during medevac flights. (2) By drawing upon this tangible example, Dr. Shaheen-Hussain illustrates many ways in which the healthcare system has and continues to perpetuate practices harmful to Indigenous Peoples in Canada.

Fighting for a Hand to Hold reinforces the existence of systemic racism in our medical system by applying the United Nations definition of genocide as a framework to illustrate Canada's history of medical colonialism against Indigenous children. (3) The book ends on the author's meditations to remedy medical colonialism, which include land-back movements, self-determination, and Indigenous sovereignty. These processes implicate the reclamation of traditional territories, stewardship over educational, cultural, social and health services, and the right to participate in political decision making. In the book's afterword, Katsi'tsakwas Ellen Gabriel provides a sobering personal reflection on the barriers to sovereignty over health care for Indigenous Peoples, emphasizing the importance of authentic reconciliation such that efforts may coalesce reparations and restitution. These efforts must centre upon the demolition of oppressive institutions and policies and the incorporation of sincere actions that demonstrate a commitment to trust rather than empty platitudes.

Towards this goal, Dr. Shaheen-Hussain asks readers to consider voice, and the ways in which a single voice may be uplifted by many. In this sense, he curates multiple quotes from Indigenous Peoples throughout the book. When discussing the memoirs of Dr. John B. Dosseter, a leading Canadian physician who performed skin grafting experiments on Inuit teenagers in the 1970s, Dr. Shaheen-Hussain quotes Paul Quassa, former Nunavut Premier and victim of these experiments: "We are not monkeys, we are not animals, we are another human being that deserves respect." (4) Quotes like these bring into sharp focus the voices of those who are so often ignored, a topic that is further discussed in the accompanying audio interview with Dr. Shaheen-Hussain, recorded in December 2020. These voices remind us, as allies, as advocates, and as Canadians, of the importance of spotlighting and listening to the perspectives of others when telling stories that are not our own. They also remind us to reconsider our intentions. Alongside the author, we must examine our actions in the context of 'do no harm'.

Many other features of the author's honest writing style are striking. For instance, he admits to his own privileges as a settler and healthcare provider. In this vulnerability, he in turn invites us to consider the consequences of our inaction. He challenges the audience to expand our notions of healthcare-inflicted harms by discussing distressing and perhaps surprising examples of Canadian medical colonialism. On a systems level, this included unethical practices whereby nutrition deprivation experiments were conducted in residential schools, Indigenous girls were forcibly sterilized, and skin grafting experiments were performed on Inuit teenagers. On an individual level, he refers to eminent Canadian physicians and researchers, like Dr. Dossetor or Dr. Lionel Bradley Pett who led the skin grafting and nutritional experiments, respectively. The justification for these experiments had been the desire to advance scientific knowledge in the field of medicine and to improve health outcomes for future patients, as evident in documented perspectives from physicians like Dr. Dosseter: "... the goals of [Dr.Dosseter's] research team were, first, to study the human leukocyte antigen (HLA) system in the Inuit and, second, to apply this knowledge to test theories about the impacts on skin grafts at the time when the field of organ transplants - including transplant rejection - was still being actively studied." (1, p.158) However, by inflicting such pains upon young test subjects who had minimal to no understanding of English, their pursuit for knowledge directed by 'beneficence' for future patients led them to ignore two other ethical pillars of medicine: to 'do no harm' and to respect 
patient autonomy. It is a powerful reminder for modern medical researchers to carefully consider the ethics and motivations of their research, including informed consent and patient autonomy.

In short, through his poignant reflections and carefully curated breadth of historical examples, Dr. Shaheen-Hussain successfully illuminates not only the complacency but the culpability of the Canadian medical system in perpetuating systemic violence against Indigenous children. He does this by relying on direct quotations from Indigenous People and offering his perspective as a medical expert. History cannot bear to repeat itself and Dr. Shaheen-Hussain engages the reader in an important dialogue on how to move forward. This book is an uncomfortable but meaningful read, especially for those interested in or belonging to the healthcare field.

Fighting for a Hand to Hold is available at your local independent bookstores, and online at Left Wing Books or McGill-Queen's University Press. The French version, Plus aucun enfant autochtone arraché: Pour en finir avec le colonialisme médical canadien published by Lux Éditeur, is available on their website.

\section{REFLECTION: A MEDICAL STU- DENT'S PERSPECTIVE}

I struggled to finish reading this book, but not for lack of interest. It was not pleasant to read about the forced transmission of smallpox in the 1860s and sterilization of Indigenous girls in the 1970s. Amid my visceral reaction of disgust, however, I realized that I had the autonomy and privilege to act on my circumstance. This was a choice that did not exist for Indigenous Peoples, who experienced violence and detrimental health outcomes at the hands of the Canadian healthcare system. Yet, despite being the subjects of centuries-long marginalization, discrimination, and genocide, Indigenous Peoples have shown extraordinary resilience by not simply surviving, but continuing to advocate for their rights to their stolen lands, self-determination and self-governance. Moreover, as Dr. Shaheen-Hussain mentions in the audio interview, these instances of vio- lence are "not an exhaustive or comprehensive study of the issue." Indeed, these inequities continue to persist. I acknowledge that my learning will continue beyond this book.

Thus, Dr. Shaheen-Hussain's humble writing encouraged me to engage in reflective practice, which is repeatedly emphasized throughout our medical training at McGill University. Change begins with a sense of ourselves, and this book has held a mirror to my own experiences as a Chinese Canadian and as a medical student.

I admit that I possess my own biases about Canada and its perceived diversity. When I first moved to Calgary, the "cleanest city in the world" (5), I envisioned it only as the place of cowboys, AAA beef, wealth, and oil. I was unprepared for the sight of the precariously housed, hopping on and off the CTrain between the freeride zone. It was almost comical to see how the expensive tailored suits jutted out from a grey backdrop of tattered and stained jackets - a visual reminder that even one of Canada's wealthiest cities was unable to care for its most vulnerable, many of whom were Indigenous. As a younger version of myself, my preconceived notions about others - as well as about my own capabilities delayed any meaningful action. Meanwhile, my memories from that time in Calgary are still tinged with the shrieking taunts of "konichiwa" across the street and the leering Caucasian male at the Calgary Stampede breathing "ching-chong, ching-chong" into my face. In those callous moments, I felt the weight of intolerance. Yet, could I condemn others for their behaviours, as I condemned my own lack thereof? I wonder now which one ultimately leads to more pain: action or inaction?

As a medical student, I have become more engaged in anti-racism, with much credit to the recent attention to the Black Lives Matters movement and increased accessibility to educational resources. In my own "activism", I have acquired a better appreciation for the role of medical education systems in promoting health equity. Notably, as a volunteer for the Anti-Racist Undergraduate Medical Education Curricular Review at McGill, which was organized by several motivated peers, I helped conduct a critical evaluation of educational materials in the pre-clerkship curriculum. This activity forced me to ex- 
amine a hidden curriculum, as Dr. Shaheen-Hussain mentions in his book. I assessed each statistic, epidemiological map, image, and sentence. In doing so, I flagged slides where skin conditions were only represented in light skin tones, maps that showed health outcomes but omitted the historical context of slavery and colonialism, images that desensitized us by overrepresenting suffering and emaciated black bodies, but rarely the healthy. I discovered how even the invention and scientific basis of some clinical measurement tools perpetuated discriminatory attitudes. For instance, the practice of race 'correction' in spirometry was based on racist studies performed on Black slaves and used to justify their position in society due to their perceived lower lung capacities. (6) Today, the use of these tools can potentially lead to inaccurate measurements of lung capacity, which can in turn underestimate disease burden and result in implications for fair compensation and treatment for Black patients. (7)

I now have more tools to address injustices than before. As a medical student, I recognize there are ways to advance healthcare beyond basic science research, which includes advocacy through medical education. With this knowledge, I am inspired to think more critically about how I choose to spend my spare time. Every step towards educating myself is now contributing to the greater goal of helping others as a healthcare professional. The question is no longer 'why am I uncomfortable with racism?', but 'how can I best serve marginalized and racialized populations as a future physician?' I recognize that being an effective advocate will require ongoing self-education.

I'll reiterate that this book is not an easy read by any means. It is distressing. However, it delivers a necessary shock and I believe readers should be educated about its content, especially for future (and current) physicians, and other allied health providers. It imparts knowledge on Canadian-Indigenous history that reminds us of our duty to prevent harm like the death of Joyce Echaquan, who was the subject of racial epithets and slurs moments before her passing. (8) As front-line providers, the lessons learned from the exploitation of Indigenous Peoples challenge us to practice culturally safe care. Many of our future patients will be of cultural backgrounds different from our own, and as much as $5 \%$ of the Canadian population is Indigenous. (9) Besides responding to diverse needs, practicing compassionate care leads to improved health outcomes. (10) By advocating for the needs of a specific group that was disproportionately affected, the \#aHandtoHold campaign effectively ended non-accompaniment for all children in remote areas of Quebec. This makes the \#aHandtoHold campaign a compelling case study that demonstrates how health policy benefits everyone, not just those who are the target of the intervention. This is the essence of equitable access to care.

Those who are moved by the traumatic stories told in Fighting for a Hand to Hold might be inspired to reflect more critically on how they can be contributors of culturally-safe clinical care to the benefit of not only Indigenous Peoples, but the diverse Canadian population at large. By detailing the history of the Canadian medical system's culpability in violence against Indigenous people, Fighting for a Hand to Hold asserts itself as an essential resource for all Canadian healthcare professionals and trainees. I hope that we can stand together in solidarity with our Indigenous patients when advocating for equitable health care, while simultaneously offering the compassionate and quality care that all Canadians deserve.

\section{3 | ACKNOWLEDGEMENTS}

I am grateful to Dr. Shaheen-Hussain for agreeing to speak with me for the interview that complements this manuscript. I am also thankful to Christine Wang for sharing ideas with me and inspiring me to engage more in matters of social justice. Finally, I would like to thank my editor, Brianna Cheng, for her tremendous help and insights on improving this manuscript.

\section{REFERENCES}

1. Shaheen-Hussain S. Fighting For a Hand to Hold. McGill-Queen's Press-MQUP; 2020.

2. ÉVAQ (Évacuations aéromédicales du Québec) 2018. Prépa- 
ration commission d'enquête. Document P-791-96.1 filed before the Public Inquiry Commission on Relations between Indigenous Peoples and Certain Public Services in Quebec (Viens Commission). 2018 Oct 10.

3. UN (United Nations) General Assembly. 1951. Convention on the Prevention and Punishment of the Crime of Genocide. Resolution 260 A (III) adopted by General Assembly resolution on 9 December 1948; Entry into force on 12 January 1951. [Accessed 2020 Dec 02]. Available from: https://www.un.org/en/genocideprevention/documents/atrocitycrimes/Doc.1_Convention\%20on\%20the\%20Prevention\%20and \%20Punishment\%20of\%20the\%20Crime\%20of\%20Genocide.pdf 4. Oudshoorn, K. 'We Are Not Monkeys' - Inuit Speak Out about Skin Grafts Done without Consent in the 1970s. CBC News. 2019 May 13. [Accessed Feb 7, 2021]. Available from: https://www.cbc.ca/news/canada/north/inuit-skin-graftsnunavut-experiment-1.5128279

5. Mourby A. Which is the cleanest city in the world? The Guardian; Jun 2015 [Accessed 2020 Dec 02]. Available from: https://www.theguardian.com/cities/2015/jun/15/cleanestcity-world-calgary-singapore

6. Braun L, Wolfgang M, Dickersin K. Defining race/ethnicity and explaining difference in research studies on lung function. European Respiratory Journal. 2013 Jun 1;41(6):1362-70. Available from: https://pubmed.ncbi.nlm.nih.gov/22878881/

7. Burney PG, Hooper RL. The use of ethnically specific norms for ventilatory function in African-American and white populations. International journal of epidemiology. 2012 Jun 1;41(3):782-90. Available from: http://europepmc.org/article/PMC/3396311

8. Slaughter G, Agecoutay C. Legislation to fight anti-Indigenous racism in health care is coming, Ottawa says. CTV News; 2021 Feb 4. [Accessed Feb 7, 2021]. Available from: https://www.ctvnews.ca/politics/legislation-to-fight-antiindigenous-racism-in-health-care-is-coming-ottawa-says1.5296678

9. Statistics Canada. 2017. Focus on Geography Series, 2016 Census. Statistics Canada Catalogue no. 98-404X2016001. Ottawa, Ontario. Data products, 2016 Census. Available from: https://www12.statcan.gc.ca/censusrecensement/2016/as-sa/fogs-spg/Facts-can-

eng.cfm? Lang $=$ EngGK $=$ CANGC $=01$ TOPIC $=9$

10. Sinclair S, Norris JM, McConnell SJ, Chochinov HM, Hack TF, Hagen NA, McClement S, Bouchal SR. Compassion: a scoping review of the healthcare literature. BMC palliative care. 2016 Dec;15(1):1-6. Available from: https://bmcpalliatcare.biomedcentral.com/articles/10.1186/ s12904-016-0080-0 